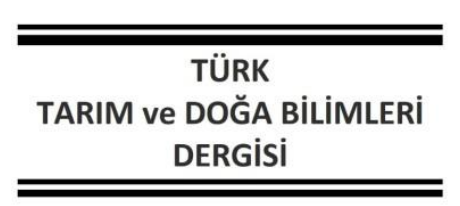

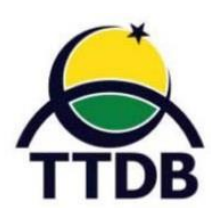

www.dergipark.gov.tr/turkjans

Araştırma Makalesi

\title{
Bazı Yulaf Genotiplerinin Morfolojik ve Tarımsal Özellikler Yönünden Genetik Farklılıklarının ve İlerlemelerinin Belirlenmesi
}

\author{
Yasemin KEÇECIOĞLU1* Rukiye KARA ${ }^{1}$, Tevrican DOKUYUCU² \\ ${ }^{1}$ Doğu Akdeniz Geçit Kuşağı Tarımsal Araştırma Enstitüsü Müdürlüğü, Kahramanmaraş, Türkiye \\ ${ }^{2}$ Kahramanmaraş Sütçü İmam Üniversitesi, Ziraat Fakültesi, Tarla Bitkileri Bölümü, Kahramanmaraş, Türkiye \\ *Sorumlu Yazar: yhisir@hotmail.com
}

Geliş Tarihi: 27.10.2020, Düzeltme Geliş Tarihi: 05.01.2021, Kabul Tarihi: 10.01.2021

Öz

Bu araştırma Kahramanmaraş koşullarında, 2006-2008 ürün yıllarında tesadüf blokları deneme desenine göre 4 tekrarlamalı olarak ekilen 8 yerel ve 9 tescilli çeşit kullanılarak yürütülmüştür. Araştırmada, genotiplerin bazı morfolojik ve tarımsal özellikler bakımından değerlendirilmesi aynı zamanda bazı tarımsal özellikler bakımından tescilli çeşitlerde tescil edildikleri yıllara göre sağlanan genetik ilerlemenin belirlenmesi amaçlanmıştır. Denemede; tane dolum periyodu, ekim-olgunlaşma süresi, $\mathrm{m}^{2}$ 'deki salkım sayısı, bitki boyu, salkım uzunluğu, salkımdaki tane sayısı, salkımdaki tane ağırlığı, tane dolum oranı, tane dolum indeksi ve tanede protein oranı incelenmiştir. İki yıllık ortalama sonuçlarına göre metrekaredeki salkım sayısı, salkımdaki tane ağırlığı, salkımdaki tane sayısı ve tanedeki protein oranı dışındaki özellikler yönünden genotipler önemli ölçüde farklı bulunmuştur.

Anahtar kelimeler: Yulaf genotipleri, morfolojik ve tarımsal özellikler

\section{Determination of Genetic Differences and Improvements of Some Oat Genotypes in Terms of Morphological and Agricultural Characteristics}

\begin{abstract}
This research was carried out by using 8 oat landraces and 9 registered oat cultivars sown in randomized complete block design with four replications between 2006-2008 years in Kahramanmaras conditions. In the study, it was aimed to evaluate the genotypes in terms of some morphological and agricultural characteristics, as well as to determine the genetic progress achieved in registered varieties in terms of some agricultural traits according to the years they were registered. In the research, grain filling period, sowing-maturity duration, number of panicle in $\mathrm{m}^{2}$, plant height, panicle height, grain number per panicle, grain weight per panicle, grain filling ratio, grain filling index and protein ratio in grain were investigated. According to the mean of two years, except for number of panicle in $\mathrm{m}^{2}$, grain weight per panicle, grain number per panicle, 1000 grain weight and protein ratio in grain genotypes were significantly different for all investigated traits.
\end{abstract}

Key words: Oat genotypes, morphological and agricultural traits

Giriş

Ülkemiz tarımında tahıl yetiştiriciliği ve hayvan besleme önemli üretim dallarından olup bu nedenle tahıl sanayi ve yem sanayi ülkemiz ekonomisinde önemli bir yer tutmaktadır. Tahıl yetiştiricileri ekim nöbeti içerisinde buğday ve arpaya alternatif olarak kullanabilecekleri bitkiler ararken, hayvan besleyen üreticilerimiz de kaliteli yem sıkıntısı çekmektedirler. Yulaf insan ve hayvan beslenmesinde kullanılan kavuzlu ve kavuzsuz tipleri olan bir bitkidir (Batalova ve ark., 2016). Yulaf, arpa ve buğdaya göre, daha sonra kültüre alınmış olup, yaklaşık 2000 yıldan beri hayvan yemi ve insan gıdası olarak kullanılmaktadır. Yulafın protein oranının \% 16' ya kadar çıkabildiği (Helland ve Holland, 2001) proteinin biyolojik değerliliği 
bakımından diğer tahıl daneleri ile uyum göstermektedir. Protein içeriğinin yüksek olması ve tanelerindeki avenin (prolamin) maddesinin genç hayvanların gelişmesindeki yararı nedeniyle besi yemi, süt yemi ve kuzu-buzağı büyütme yemleri gibi alternatif yemler üreten yem sanayi için yulaf önemli bir hammadde özelliğine sahiptir (Dumlupınar, 2010). Ayrıca yulaf samanı buğdaygil samanlarının en iyilerindendir (Kün, 1983), sapları daha yumuşak, yaprağı daha bol olmasından dolayı organik ve mineral maddelerce buğday ve arpa samanından daha üstündür (Yılmaz, 1996).

Son yıllarda hem dünyada hem de ülkemizde sağlıklı ve dengeli beslenme anlayışı artmakta, bu anlayış diğer alternatif ürünler yanında yulafı da ön plana çıkarmaktadır. İnsan beslenmesinde yulafın öneminin artmasından dolayı tane kalitesi ve buna bağlı karakterlerde yapılan çalışmalarda bir seçim kriteri olmaktadır (Buerstmayr ve ark., 2007). Yapılan araştırmalarda insan ve hayvan sağlığı açısından yulafın önemli antioxidant maddeler içerdiği (Dokuyucu ve ark., 2003; Peterson ve ark., 2005), kolesterolü düşürücü etki yapan lif içeriğinin yüksek ve demir içeriğinin ise zengin olduğu ortaya konulmuştur (Wood, 2001). Yulaf $\mathrm{Ca}, \mathrm{Cu}$ ve $\mathrm{Co}$ bakımından yetersizdir. Buna karşın $\mathrm{P}$, Fe ve Mn'ca zengindir. Ayrıca kavuzu fazla miktarda Si içerir. Dane ve yağında çok az miktarda $A, D$ ve $E$ vitaminleri bulunur (Karabulut, 1995). Ayrıca, çözünür lif beta-glukan içeren yulaf unu günde 5-10 g tüketildiğinde kalp hastalığı riskini azalttığı bildirilmektedir (Coşkun, 2005). Yulafın diğer bir kullanım alanı da endüstride sıvı aldehit üretimidir. Yulaf kavuzlarından elde edilen furfural maddesinden endüstride sıvı aldehit yapılmakta ve aldehit, yağ rafinerileri ile plastik yapımında değerlendirilmekte, ayrıca kavuzlarından tıbbi ilaç yapımında da yararlanılmaktadır (Yürür, 1994).

Kültürü yapılan beyaz yulafların (Avena sativa L.) ve kırmızı yulafların (Avena byzantina Koch.) kökeninin Anadolu olduğu bildirilmektedir (Kün, 1988). Bu gen kaynaklarının değerlendirilmesi amacıyla, o dönemdeki adlarıyla Eskişehir Tohum Islah İstasyonu, Yeşilköy Tohum Islah İstasyonu, Ankara Tohum Islah İstasyonu ve Ankara Üniversitesi Ziraat Fakültesi tarafından, bazı seleksiyon çalışmaları yürütülmüş olup, bu çalışmalar sonucunda bazı çeşitlerin seçilerek üreticiye dağıtıldığı bildirilmiştir (Kün, 1988). Daha sonra Gen kaynaklarının korunması amacıyla yapılan çalışmalar çerçevesinde Ege Tarımsal Araştırma Enstitüsü bünyesinde kurulan Bitki Gen Kaynakları Bölümü, Bahri Dağdaş Uluslararası Tarımsal Araştırma Enstitüsü ve IPK (Institute of
Plant Genetics and Crop Plant Research Gatersleben) tarafından ülkemizdeki yerel yulaf çeşitleri toplanarak koruma altına alınmıştır. Ancak yerel yulaf materyalleri toplanmış olmasına rağmen, ülkemiz koşullarında bu yerel çeşitlerin farklı çevrelere adaptasyonu ve sahip olduğu özellikler bakımından mevcut genetik varyasyonun belirlenmesi konusunda yeterince çalışma yapılamamıştır. Özberk (2018) yerel çeşitleri, zamanla belirli bir bölgeye uyum sağlamış ancak ıslahla geliştirilmemiş, ayırt edici özellikleri bulunan dinamik populasyonlar şeklinde tanımlamıştır. Yerel çeşitlerin uzun yıllar aynı bölgede yetiştirilmelerinden dolayı bölgedeki biyotik ve abiyotik stres faktörlerine karşı dayanıklılık kazandıkları kabul edilmektedir. Islah programlarında bu dayanıklılık özelliklerinin yeni çeşitlere aktarılmasında anaç olarak kullanımı yaygındır (Sönmez ve Karaduman, 2020). Ülkemiz yulafın gen merkezi olmasına rağmen ülkemizdeki yerel çeşitlerin birçok özelliği bilinmemektedir. Özellikleri bilinmeyen genetik materyaller gerek pratik tarımda, gerekse bitki ıslahı çalışmalarında kullanılamamaktadır. Ülkemizdeki yerel çeşitlerin özelliklerinin ortaya konulması ve detaylı bir şekilde değerlendirilmesi ileride yapılacak yulaf yetiştiriciliği ve ıslahı bakımından önem taşımaktadır.

Kün (1988) tarafından yerel yulaf materyalleri arasında birçok özellik bakımı ile doğrudan seçilip tescil edilebilecek düzeyde formların bulunduğu belirtilmesine rağmen bu gen kaynağı yeterince değerlendirilmemiştir. Bu nedenle bu çalışmada ülkemizde yaygın olarak yetiştirilen yerel yulaf genotipleri ile tescil edilmiş çeşitlerin morfolojik ve tarımsal özellikleri bakımından incelenmesi, bu özellikler bakımından genetik varyasyonun ortaya konulması ve bu mevcut varyasyonun belirlenmesi farklı çevrelerde yetiştirilebilecek yerel yulaf genotiplerinin belirlenmesini ve ürün çeşitliliğinin artırılmasını sağlayabilecektir. Böylece öncelikli olarak genotiplerin Kahramanmaraş ve benzeri bölge koşulları için değerlendirilmesi amaçlanmıştır.

$\mathrm{Bu}$ çalışmada; i) ülkemizde yaygın olarak üretilen bazı yerel çeşitler ile tescil edilmiş yulaf çeşitlerinin bazı morfolojik ve tarımsal özellikler bakımından değerlendirilmesi ve özelliklerinin ortaya konulması, ii) araştırmada standart olarak kullanılan ve 1960 ’lı yıllardan günümüze kadar tescil edilmiş yulaf çeşitlerimizde incelenen özellikler bakımından sağlanan genetik ilerlemenin belirlenmesi amaçlanmıştır. 


\section{Materyal ve Yöntem}

Bu çalışma, 2006-2008 ürün yıllarında, Kahramanmaraş Sütçü İmam Üniversitesi Ziraat Fakültesi Tarla Bitkileri Bölümünün, araştırma sahası olarak kullandığı Doğu Akdeniz Geçit Kuşağı Tarımsal Araştırma Enstitüsü deneme alanında yapılmıştır.

Araştırmada, Bahri Dağdaş Uluslararası Tarımsal Araştırma Enstitüsü'nden sağlanan ve ülke genelinde yaygın olarak üretilen 8 yerel ve 9 tescil edilmiş yulaf çeşidi araştırmada materyal olarak kullanılmıştır. Denemede kullanılan genotiplerin adı ve tescilli çeşitlerin tescil yılları Çizelge 2.'de verilmiştir.

Çizelge 1. den görüldüğü gibi, Kahramanmaraş'ta uzun yıllar ortalamasına göre yıllık yağış miktarı 668.4 mm'dir. Araştırmanın yürütüldüğü 2006-07 ve 2007-08 ürün yıllarındaki yıllık toplam yağışlar sırasıyla 522.2 ve $550.1 \mathrm{~mm}$ olmuştur. Yağışın miktarı yanında, vejetasyon periyodu içerisindeki dağılımı da yıllar arasında önemli farklılık göstermiştir. Denemenin yürütüldüğü ürün yıllarında, özellikle bitkilerin çimlenme, çıkış ve ilk büyümesinin gerçekleştiği dönem olan Kasım-Aralık aylarında, yağış miktarının özellikle de birinci ürün yılında uzun yıllar ortalamasından daha düşük olduğu görülmektedir. Bunun sonucu olarak birinci deneme yılında çimlenme ve çıkış problemi gözlenmiştir. Buna karşılık, bitkilerin generatif gelişme (gebecik, salkım çıkışı, çiçeklenme, döllenme, tane dolumu) gösterdikleri Şubat, Mart, Nisan ve Mayıs aylarındaki yağış miktarı bakımından ise birinci ürün yılı ikinci ürün yılından ve uzun yıllar ortalamasından daha fazla olmuştur (Çizelge 1).

Çizelge 1. Deneme yılları ve uzun yıllar ortalamasına ait bazı iklim verileri

\begin{tabular}{|c|c|c|c|c|c|c|c|c|c|}
\hline \multirow[b]{2}{*}{ Aylar } & \multicolumn{3}{|c|}{ Yağış (mm) } & \multicolumn{3}{|c|}{ Sıcaklık $\left({ }^{\circ} \mathrm{C}\right)$} & \multicolumn{3}{|c|}{ Nispi nem (\%) } \\
\hline & $2006-07$ & 2007-08 & $\begin{array}{l}\text { Uzun } \\
\text { Yillar }\end{array}$ & $2006-07$ & 2007-08 & $\begin{array}{l}\text { Uzun } \\
\text { yıllar }\end{array}$ & $2006-07$ & $2007-08$ & $\begin{array}{l}\text { Uzun } \\
\text { yıllar }\end{array}$ \\
\hline Kasım & 77.0 & 105.9 & 90.2 & 10.3 & 13.2 & 11.4 & 60.6 & 64.1 & 64.0 \\
\hline Aralık & 1.1 & 96.2 & 128.1 & 6.8 & 6.1 & 6.6 & 53.3 & 65.5 & 71.0 \\
\hline Ocak & 63.1 & 78.6 & 122.6 & 4.9 & 3.3 & 4.9 & 63.5 & 55.0 & 70.0 \\
\hline Şubat & 133.6 & 121.5 & 110.1 & 7.8 & 5.5 & 6.3 & 71.2 & 61.4 & 65.0 \\
\hline Mart & 99.9 & 69.5 & 95.0 & 11.4 & 14.4 & 10.4 & 57.9 & 59.6 & 60.0 \\
\hline Nisan & 87.8 & 54.7 & 76.3 & 13.3 & 18.1 & 15.3 & 57.6 & 55.5 & 58.0 \\
\hline Mayıs & 58.9 & 23.7 & 39.9 & 23.4 & 20.2 & 20.4 & 59.1 & 56.5 & 54.0 \\
\hline Haziran & 0.8 & 0.0 & 6.2 & 27.5 & 27.3 & 25.1 & 49.8 & 49.8 & 50.0 \\
\hline Toplam & 522.2 & 550.1 & 668.4 & & & & & & \\
\hline Ortalama & & & & 13.2 & 13.5 & 12.6 & 59.1 & 58.4 & 61.5 \\
\hline
\end{tabular}

Her iki ürün yılında da deneme yeri topraklarının bünye sınıfı tınlı tekstür olduğu ortaya çıkmıştır. Deneme yeri topraklarının 0-30 cm ve $30-$ $60 \mathrm{~cm}$ 'de $\mathrm{pH}^{\prime}$ sı sırasıyla ilk yılda 7.67 ile 7.57 , ikinci yılda ise 7.55 ile 7.54 , kireç oranı ise ilk yıl \% 23.00 ile 24.90, ikinci yıl ise \% 26.92 ile 26.73 sınırları arasında belirlenmiştir. Elverişli fosfor miktarı sırasıyla ilk yılda 4.85 ile $3.68 \mathrm{~kg} / \mathrm{da}$, ikinci yılda 4.80 ile $4.50 \mathrm{~kg} / \mathrm{da}$, elverişli potasyum miktarı ilk yıl 93.75 ile $76.38 \mathrm{~kg} / \mathrm{da}$, ikinci yıl 40.10 ile $68.20 \mathrm{~kg} / \mathrm{da}$ arasında belirlenmiştir. Organik madde oranları ilk yılda 0-30 cm'de \% 1.06 olurken $30-60 \mathrm{~cm}$ 'de \% 0.85 ; ikinci yılda ise $0-30 \mathrm{~cm}$ 'de $\% 1.85$ olurken 30 $60 \mathrm{~cm}$ 'de \% 1.93 olarak bulunmuştur.

Araştırma, tesadüf blokları deneme desenine göre 4 tekrarlamalı olarak kurulmuştur. Her iki yılda da ekimle birlikte 20-20-0 kompoze gübresi kullanılarak, dekara $8 \mathrm{~kg} \mathrm{~N}$ ve $8 \mathrm{~kg} \mathrm{P}_{2} \mathrm{O}_{5}$ olacak şekilde gübreleme yapılmıştır. Ayrıca, ilk yıl; kardeşlenme ve sapa kalkma dönemlerinde 5'er $\mathrm{kg} / \mathrm{da}$ olmak üzere, toplam $10 \mathrm{~kg} / \mathrm{da}$, ikinci yıl ise kardeşlenme dönemi sonunda toplam $10 \mathrm{~kg} / \mathrm{da} \mathrm{N}$
(\%33 $\mathrm{NH}_{4} \mathrm{NO}_{3}$ formunda) uygulanmıştır. Hasat zamanı, her parselin başından ve sonundan $50 \mathrm{~cm}$, parsellerin kenarlarından ise 1'er sıra kenar tesiri olarak atılarak, geri kalan alandan $\left(4.48 \mathrm{~m}^{2}\right)$ gözlem ve ölçümler alınmıştır.

Araştırmada, Zadoks (1974), ıskalası esas alınarak farklı gelişme dönemlerinde belirtilen gözlem ve ölçümler alınmıştır. Tane dolum periyodu (TDP: çiçeklenme tarihinden olgunlaşmaya kadar geçen süre), ekim olgunlaşma süresi (EOS: ekimden\% 75 tam oluma kadar geçen süre), metrekaredeki salkım sayısı (MSS: olgunlasma döneminde her parselin orta kısmındaki 4 sıradan sansa bağlı olarak seçilen 1'er metrelik kısımdaki salkımlar sayılarak bulunmuştur), bitki boyu (BB: Olgunlaşma döneminde 10 bitkinin ana sapında, toprak seviyesinden kılçıklar hariç en üst başakçık ucuna kadar olan uzunluk $\mathrm{cm}$ olarak ölçülerek bulunmuştur), salkım uzunluğu (SU: bitki boyunun belirlendiği 10 bitkinin ana sapına ait salkımlar $\mathrm{cm}$ olarak ölçülmüştür), salkımdaki tane sayısı (STS: Olgunlaşma döneminde, her parselden tesadüfi 
olarak seçilen 10 bitkinin ana sapına ait salkımlar, ayrı ayrı harman edilerek taneleri sayılmış ve bunların ortalamaları alınarak salkımdaki tane sayısı bulunmuştur), salkımdaki tane ağırlığı (STA: salkımdaki taneler sayıldıktan sonra tartılarak bunların ortalamaları alınmıştır), tane dolum oranı (TDO: Hasat olgunluğu dönemindeki ortalama tane ağırlığının (mg), çiçeklenmeden fizyolojik olgunluk dönemine kadar geçen gün sayısına oranlanması ile hesaplanmış), tane dolum indeksi (TDi: Tane dolum periyodunun, ekimden olgunlaşmaya kadar geçen gün sayısına oranlanması ile hesaplanmıştır) ve tanede protein oranı (TPO: Her parselden elde edilen tanelerde Dumas metoduna göre $\mathrm{N}$ analizi yapılmış olup, elde edilen $\mathrm{N}$ değerleri 5.83 katsayısı ile çarpılarak protein oranı belirlenmiştir) incelenmiştir. Belirtilen karakterlere ait veriler SAS (SAS, 1999) paket programı kullanılarak varyans analizine tabi tutulmuş, genotip ortalamalarının karşılaştırılmasında Duncan çoklu karşılaştırma testi kullanılmıştır. Korelasyon ve Regresyon analizi SAS (SAS, 1999) paket programı kullanılarak yapılmıştır.

Çizelge 2. Denemede kullanılan genotiplerin adı ve tescil yılları

\begin{tabular}{ccc}
\hline Genotip no & Genotipler & Tescil yılı \\
\hline $\mathbf{1}$ & Ankara-76 & 1975 \\
$\mathbf{2}$ & Ankara-84 & 1975 \\
$\mathbf{3}$ & Apak 2-3 & 1963 \\
$\mathbf{5}$ & Bozkır 1-5 & 1963 \\
6 & Faikbey & 2004 \\
$\mathbf{7}$ & Checota & 1986 \\
8 & Seydişehir & 2004 \\
9 & Yeşilköy 330 & 1975 \\
10 & Yeşilköy-1779 & 1964 \\
11 & Erzurum & \\
12 & Amasya & \\
13 & Antalya & \\
14 & Tokat & \\
16 & Ordu & \\
17 & Sivas & \\
\hline
\end{tabular}

\section{Bulgular ve Tartışma \\ Tane dolum periyodu}

Tane dolum periyodu yönünden genotipler arasındaki farklar istatistiki olarak yıllar ve genotip $\mathrm{x}$ yıl interaksiyonu bakımından önemli ( $P \leq 0.01$ ) bulunmuştur. Genotiplerin tane dolum periyodu, ilk yıl 22.00-33.50 gün arasında, ikinci yıl ise 23.50 30.50 gün arasında değişmiştir. İki yılın ortalaması olarak Sivas ve Yeşilköy-330 genotipleri 31.00 ve 30.75 ile en uzun tane dolum periyoduna sahip genotipler olarak belirlenmiştir. Faikbey çeşidi 24.12 gün ile en kısa tane dolum periyoduna sahip çeşit olmuştur (Çizelge 3).

Birinci ürün yılında tane dolum periyodu 28.63 gün iken, ikinci ürün yılında 26.64 gün olmuştur (Çizelge 3). Birinci ürün yılında aktif büyüme dönemi olan Şubat, Mart, Nisan ve Mayıs aylarındaki iklim koşullarının ikinci ürün yılına göre daha elverişli olması, birinci ürün yılında daha uzun tane dolum periyodu değerlerinin elde edilmesine neden olmuştur. Wych ve ark. (1982), genotiplerin tane dolum periyodu bakımından yıllar arasında önemli farklılıklar oluştuğunu, bu dönemde meydana gelen nem yetersizliği ve yüksek sıcaklıkların tane dolum periyodunu önemli derecede sınırladığı tespit edilmiştir (Öztürk ve Akkaya, 1994). Ayrıca, Ercan ve ark. (2016)'da yaptıkları bir çalışmada tane dolum periyodu yönünden genotipler arasındaki farkların önemli olduğunu belirtmişlerdir. Yapılan başka bir çalışmada ise iki yıllık varyans analizine göre sadece yıllar arasında ki fark istatistiki olarak önemli bulunmuştur (Dumlupınar ve ark., 2017).

Tescilli çeşitler (Apak 2-3, Bozkır 1-5, Yeşilköy - 1779, Ankara -76, Ankara - 84, Yeşilköy - 330, Checota, Faikbey ve Seydişehir) tescil yılları dikkate alınarak 1960'da 1970, 1980 ve 2000'li yıllar olacak şekilde 4 grupta sınıflandırılmıştır. Tane dolum periyodu bakımından yulaf çeşitlerinin tescil yıllarına göre yapılan Linear regresyon analizinde, $y=$ $-0.0288 x+84.5$ şeklinde linear bir ilişkinin olduğu saptanmıştır. Linear ilişkiye ait $\mathrm{R}^{2}$ değerinin \% 4.5 olması, ilişkinin tane dolum periyodu varyasyonun ancak \% 4.5'ni açıklayabildiğini göstermektedir (Şekil 1). 
Çizelge 3. Yulaf genotiplerinin tane dolum periyodu ve ekim-olgunlaşma süresine ilişkin ortalama değerler

\begin{tabular}{lcccccc}
\hline \multirow{2}{*}{ Genotipler } & \multicolumn{2}{c}{ Tane dolum periyodu (gün) } & \multicolumn{2}{c}{ Ekim olgunlaşma süresi (gün) } \\
\cline { 2 - 6 } & 1. Yıl & 2. Yıl & Ort. & 1. Yıl & 2. Yıl & Ort. \\
\hline Ankara-76 & $31.00 \mathrm{abc}$ & $25.50 \mathrm{bcde}$ & $28.25 \mathrm{bcd}$ & $200.00 \mathrm{def}$ & $193.50 \mathrm{~d}$ & $196.75 \mathrm{cde}$ \\
Ankara-84 & $31.25 \mathrm{abc}$ & $27.00 \mathrm{abcde}$ & $29.12 \mathrm{abc}$ & $199.25 \mathrm{efg}$ & $193.50 \mathrm{~d}$ & $196.38 \mathrm{de}$ \\
Apak2-3 & $26.50 \mathrm{def}$ & $26.25 \mathrm{bcde}$ & $26.37 \mathrm{def}$ & $201.50 \mathrm{bcd}$ & $195.75 \mathrm{abcd}$ & $198.63 \mathrm{ab}$ \\
Bozkır1-5 & $25.50 \mathrm{ef}$ & $24.75 \mathrm{de}$ & $25.12 \mathrm{ef}$ & $201.50 \mathrm{bcd}$ & $194.75 \mathrm{bcd}$ & $198.13 \mathrm{abc}$ \\
Faikbey & $22.00 \mathrm{~g}$ & $26.25 \mathrm{bcde}$ & $24.12 \mathrm{f}$ & $194.00 \mathrm{~h}$ & $197.75 \mathrm{a}$ & $195.88 \mathrm{e}$ \\
Checota & $29.00 \mathrm{~cd}$ & $30.50 \mathrm{a}$ & $29.75 \mathrm{ab}$ & $198.50 \mathrm{fg}$ & $196.50 \mathrm{ab}$ & $197.50 \mathrm{bcd}$ \\
Seydişehir & $28.50 \mathrm{cde}$ & $25.25 \mathrm{cde}$ & $26.87 \mathrm{cde}$ & $198.50 \mathrm{fg}$ & $195.25 \mathrm{bcd}$ & $196.88 \mathrm{cde}$ \\
Yeşilköy-330 & $32.25 \mathrm{ab}$ & $29.25 \mathrm{ab}$ & $30.75 \mathrm{a}$ & $204.50 \mathrm{a}$ & $194.75 \mathrm{bcd}$ & $199.63 \mathrm{a}$ \\
Yeşilköy-1779 & $28.25 \mathrm{cde}$ & $28.00 \mathrm{abcd}$ & $28.12 \mathrm{bcd}$ & $201.00 \mathrm{cde}$ & $196.25 \mathrm{abc}$ & $198.63 \mathrm{ab}$ \\
Erzurum & $23.50 \mathrm{fg}$ & $25.75 \mathrm{bcde}$ & $24.62 \mathrm{ef}$ & $197.50 \mathrm{~g}$ & $194.75 \mathrm{bcd}$ & $196.13 \mathrm{de}$ \\
Amasya & $26.50 \mathrm{def}$ & $23.50 \mathrm{e}$ & $25.00 \mathrm{ef}$ & $199.50 \mathrm{defg}$ & $193.50 \mathrm{~d}$ & $196.50 \mathrm{cde}$ \\
Antalya & $32.25 \mathrm{ab}$ & $25.50 \mathrm{bcde}$ & $28.87 \mathrm{abc}$ & $200.25 \mathrm{def}$ & $195.75 \mathrm{abcd}$ & $198.00 \mathrm{abc}$ \\
Tokat & $33.00 \mathrm{a}$ & $27.00 \mathrm{abcde}$ & $30.00 \mathrm{ab}$ & $202.50 \mathrm{abc}$ & $193.75 \mathrm{~cd}$ & $198.13 \mathrm{abc}$ \\
Ordu & $27.75 \mathrm{de}$ & $24.75 \mathrm{de}$ & $26.25 \mathrm{def}$ & $201.00 \mathrm{cde}$ & $195.25 \mathrm{bcd}$ & $198.13 \mathrm{abc}$ \\
Sivas & $33.50 \mathrm{a}$ & $28.50 \mathrm{abcd}$ & $31.00 \mathrm{a}$ & $203.00 \mathrm{abc}$ & $194.75 \mathrm{bcd}$ & $198.88 \mathrm{ab}$ \\
Çanakkale-Ovacık Köy & $29.50 \mathrm{bcd}$ & $26.25 \mathrm{bcde}$ & $27.87 \mathrm{bcd}$ & $203.50 \mathrm{ab}$ & $194.50 \mathrm{bcd}$ & $199.00 \mathrm{ab}$ \\
Samsun Ladik-ibiköyü & $26.50 \mathrm{def}$ & $29.00 \mathrm{abc}$ & $27.75 \mathrm{bcd}$ & $201.50 \mathrm{bcd}$ & $197.00 \mathrm{ab}$ & $199.25 \mathrm{a}$ \\
\hline Ortalama & $28.63 * *$ & $26.64 * *$ & $27.63 * *$ & $200.44 * *$ & $195.13 * *$ & $197.79 * *$ \\
\hline
\end{tabular}

** $\mathrm{P}<0.01$ düzeyinde önemli

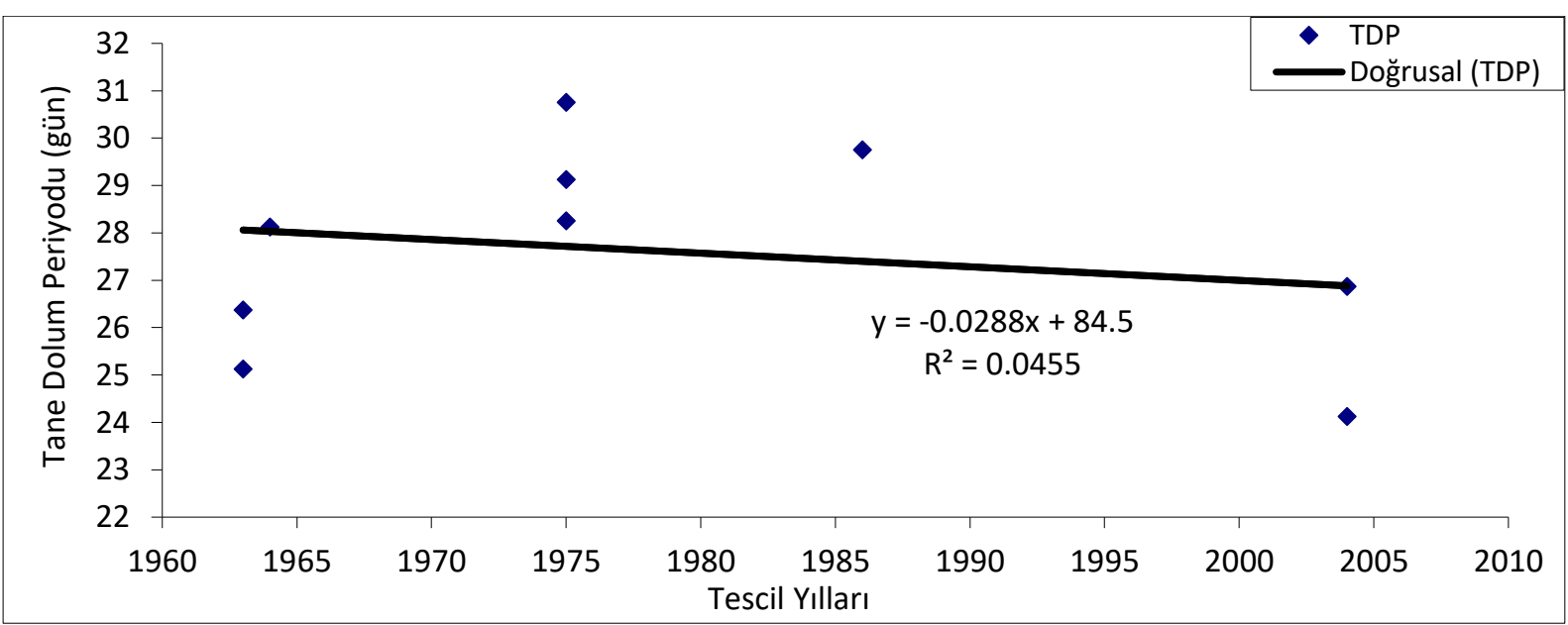

Şekil 1. Tane dolum periyodu ile tescil yılları arasındaki ilişki (1960-2005).

\section{Ekim - olgunlaşma süresi}

Ekim olgunlaşma süresi, yıllar ve genotip $\mathrm{x}$ yıl interaksiyonu bakımından istatistiki olarak önemli $(P \leq 0.01)$ bulunmuştur. Denemenin birinci yılında, en uzun ekim - olgunlaşma gün süresi 204.50 gün ile Yeşilköy-330 çeşidinden elde edilmiş, en kısa gün ise 194.00 gün ile Faikbey çeşidinden elde edilmiştir (Çizelge 3). Denemenin ikinci yılında, 197.75 gün ile Faikbey en uzun ekim - olgunlaşma süresine sahip olurken, 193.50 gün ile Amasya, Ankara - 76 ve Ankara - 84 genotipleri kısa ekim - olgunlaşma gün süresine sahip olmuşlardır. İki yılın ortalaması olarak, 199.62 gün ile Yeşilköy- 330 ve 199.25 gün ile Samsun Ladik - ibiköy genotipleri en uzun ekim olgunlaşma gün sayısına sahip olup, en kısa ekim - olgunlaşma süresi ise 195.87 gün ile Faikbey çeşidinden elde edilmiştir.

Birinci yıl, ekim - olgunlaşma süresi 200.44 gün bulunurken, ikinci yılda 195.13 gün olarak belirlenmiştir. Birinci yılda ekim - olgunlaşma süresi ikinci yıla göre daha uzun olmuştur. Birinci yılda Faikbey çeşidi hariç diğer genotiplerin hepsi ikinci yıldan daha yüksek değere sahip olmuş ve yıl $x$ genotip interaksiyonunun oluşmasına neden olmuştur. Daha önce yapılan bir çalışmada da buğdayda, ekim-olgunlaşma süresi bakımından yıl x genotip interaksiyonun önemli olduğu belirtilmiştir (Öztürk ve Akaya, 1994). Dumlupınar ve ark., (2017)'de yaptıkları bir çalışmada ekim olgunlaşma süresi bakımından iki yılık veriler üzerinden yapılan 
varyans analizinde ise, genotip, yıl ve yıl x genotip istatistiki olarak önemli bulmuşlardır. Genotiplerin olgunlaşmaları için intiyaç duydukları toplam sıcaklıkların genetik olarak farklı olması, ekim olgunlaşma süresinin yıllara göre farklı olmasına ve yıl $x$ genotip interaksiyonunun önemli çıkmasına neden olduğunu bildirmişlerdir.

\section{Metrekaredeki salkım sayısı}

Metrekaredeki salkım sayısı bakımından genotipler arasındaki farklar her iki yılda ve genotip $\mathrm{x}$ yıl interaksiyonu bakımından istatistiki olarak önemsiz olmuştur. Denemenin birinci yılında metrekaredeki salkım sayısı 775.50 adet $/ \mathrm{m}^{2}$ ile 475.25 adet $/ \mathrm{m}^{2}$ arasında, ikinci yılda ise 580.00 adet $/ \mathrm{m}^{2}$ ile 446.25 adet $/ \mathrm{m}^{2}$ arasında tespit edilmiştir (Çizelge 4).
Yılmaz (1996), yulafta yaptığı bir çalışmada salkım sayısı bakımından genotipler arasındaki farkların önemsiz olduğunu bildirmiştir. Ayrıca, Browne ve ark., (2006) ve Kara ve ark., (2007), bizim çalışmamızın aksine, yulafta metrekaredeki salkım sayısı bakımından genotipler arasında farklılıklar olduğunu bildirmişlerdir.

Denemede, salkım sayısı bakımından yıllar arasındaki fark önemli bulunmuştur $(P \leq 0.01)$. Bu durum araştırmanın birinci yılında Şubat, Mart, Nisan ve Mayıs aylarındaki yağış miktarının ikinci yıla göre daha yüksek olması Mart ve Nisan aylarındaki ortalama sıcaklık değerlerinin daha düşük olması gibi nedenlerle kardeşlenme miktarının artmasından kaynaklanabilir.

Çizelge 4. Yulaf genotiplerinin metrekaredeki salkım sayısı ve bitki boyuna ilişkin ortalama değerler

\begin{tabular}{lcccccc}
\hline & \multicolumn{2}{c}{ Metrekaredeki salkım sayısı (adet) } & \multicolumn{3}{c}{ Bitki boyu (cm) } \\
\cline { 2 - 6 } Genotipler & 1. Yıl & 2. Yıl & Ort. & 1. Yıl & 2. Yıl & Ort. \\
\hline Ankara-76 & 650.50 & 485.00 & 567.75 & $135.40 \mathrm{bcde}$ & 130.75 & $133.07 \mathrm{bc}$ \\
Ankara-84 & 722.75 & 520.00 & 621.38 & $130.55 \mathrm{e}$ & 130.50 & $130.52 \mathrm{bc}$ \\
Apak2-3 & 645.25 & 502.50 & 573.88 & $146.50 \mathrm{ab}$ & 134.00 & $140.25 \mathrm{ab}$ \\
Bozkır1-5 & 602.25 & 547.50 & 574.88 & $146.75 \mathrm{ab}$ & 137.00 & $141.87 \mathrm{ab}$ \\
Faikbey & 559.00 & 446.25 & 502.63 & $145.95 \mathrm{abc}$ & 135.00 & $140.47 \mathrm{ab}$ \\
Checota & 638.00 & 468.75 & 553.38 & $141.65 \mathrm{abcde}$ & 139.00 & $140.32 \mathrm{ab}$ \\
Seydişehir & 775.50 & 555.00 & 665.25 & $138.45 \mathrm{abcde}$ & 131.50 & $134.97 \mathrm{bc}$ \\
Yeşilköy-330 & 628.75 & 570.00 & 599.19 & $132.77 \mathrm{cde}$ & 121.00 & $126.88 \mathrm{c}$ \\
Yeşilköy-1779 & 475.25 & 528.75 & 502.00 & $144.25 \mathrm{abcd}$ & 127.75 & $136.00 \mathrm{abc}$ \\
Erzurum & 680.75 & 538.75 & 609.75 & $150.85 \mathrm{a}$ & 131.75 & $141.30 \mathrm{ab}$ \\
Amasya & 683.50 & 501.25 & 592.38 & $140.95 \mathrm{abcde}$ & 133.50 & $137.22 \mathrm{abc}$ \\
Antalya & 710.75 & 532.50 & 621.63 & $131.95 \mathrm{de}$ & 136.50 & $134.22 \mathrm{bc}$ \\
Tokat & 692.00 & 491.25 & 591.63 & $143.75 \mathrm{abcde}$ & 129.75 & $136.75 \mathrm{abc}$ \\
Ordu & 575.75 & 525.00 & 550.38 & $151.55 \mathrm{a}$ & 142.75 & $147.15 \mathrm{a}$ \\
Sivas & 702.75 & 557.50 & 630.13 & $144.95 \mathrm{abcd}$ & 118.25 & $131.60 \mathrm{bc}$ \\
Çanakkale-Ovacık Köy & 651.75 & 580.00 & 615.88 & $146.75 \mathrm{ab}$ & 126.50 & $136.62 \mathrm{abc}$ \\
Samsun Ladik-ibiköyü & 614.75 & 541.25 & 578.00 & $145.85 \mathrm{abc}$ & 131.00 & $138.42 \mathrm{ab}$ \\
\hline Ortalama & 647.58 & 523.01 & 585.29 & $142.28 * *$ & 131.55 & $136.92 * *$ \\
\hline$* *$ P<0.01 düzeyinde önem & & & &
\end{tabular}

\section{Bitki boyu}

Bitki boyu bakımından genotipler arasındaki farklar, birinci yılda ve iki yıllık ortalamalara göre önemli ( $P \leq 0.01)$, ikinci yılda ise istatistiki olarak önemsiz olmuştur. Genotiplerin bitki boyları, ilk yıl $130.55-151.55 \mathrm{~cm}$ arasında ikinci yılda $142.75 \mathrm{~cm}$ ile $118.25 \mathrm{~cm}$ arasında değişmiştir. İki yıllık ortalama sonuçlar birlikte değerlendirildiğinde, Ordu genotipi $147.15 \mathrm{~cm}$ ile en uzun bitki boyuna sahip olmuştur. Yeşilköy-330 çeşidi ise $126.88 \mathrm{~cm}$ ile en kısa boy uzunluğa sahip olmuştur (Çizelge 4). Bizim bulgularımıza benzer şekilde, yapılan bazı çalışmalarda bitki boyu yönünden genotipler arasındaki farkların önemli olduğu bildirilmiştir (Ercan ve ark.,2016; Dumlupınar ve ark., 2017). Kara ve ark. (2007) yaptığı çalışmada Ordu genotipini bitki boyu yönünden en uzun bulurken, Yılmaz, (1996) yaptığı çalışmada Yeşilköy-330 çeşidini en kısa bitki boyu olarak saptamıştır. Buerstmayr ve ark. (2007), bitki boyu yönünden çeşitler arasındaki farkların önemli çıktığını ve bitki boylarının 80.4 ile $140.4 \mathrm{~cm}$ arasında değiştiğini, ortalamasının ise $115.1 \mathrm{~cm}$ olduğunu belirtmişlerdir. Jaradat ve ark. (1996) ise, uzun boylu yerel genotiplerin tane verim potansiyelinin kısa boylu genotiplerden $\% 30$ daha az olduğunu, yerel genotiplerin biyomaslarının ıslah genotiplerine nazaran daha uzun olduğunu bildirmişlerdir.

Bitki boyu yönünden yıllar arasındaki fark istatistiksel olarak önemli $(P \leq 0,01)$ bulunmuştur. 
Bitki boyu ortalamaları birinci yılda $142.28 \mathrm{~cm}$, ikinci yılda $131.55 \mathrm{~cm}$ olarak elde edilmiştir. Birinci yılda, özellikle de bitki büyümesinin hızlandığı ilkbahar dönemindeki yağış miktarının fazla olması, bitki boyunun daha uzun olmasına neden olmuştur. Bitki boyunun belirlenmesinde, yağışın hangi dönemde olduğu önem kazanmakta, özellikle sapa kalkma döneminde meydana gelen düşük yağışın bitki boyunda azalmaya neden olduğu belirtilmektedir (Gupta ve ark., 2001). Denemede yıl x genotip interaksiyonu önemsiz bulunmuştur (Çizelge 4).

\section{Salkım uzunluğu}

Salkım uzunluğu yönünden genotipler arasındaki farklar birinci yıl, ikinci yıl ve iki yıllık ortalama sonuçlara göre önemli bulunmuştur ( $P \leq$ 0.01). Genotiplerin salkım uzunluğu değerleri birinci yılda $38.90 \mathrm{~cm}$ ile $25.17 \mathrm{~cm}$ arasında ikinci yılda ise $33.40 \mathrm{~cm}$ ile 24.12 arasında değişmiştir (Çizelge 5). İki yıllık ortalamalara göre ise salkım uzunlukları $35.58 \mathrm{~cm}$ ile $24.65 \mathrm{~cm}$ arasında olmuştur. Yeşilköy330 çeşidi her iki yılda ve iki yıllık ortalamalara göre en kısa salkım uzunluğuna sahip olmuştur.

Çizelge 5. Yulaf genotiplerinin salkım uzunluğu ve salkımdaki tane sayısına ilişkin ortalama değerler

\begin{tabular}{lcccccc}
\hline \multirow{2}{*}{ Genotipler } & \multicolumn{3}{c}{ Salkım uzunluğu $(\mathrm{cm})$} & \multicolumn{2}{c}{ Salkımdaki tane sayısı (adet) } \\
\cline { 2 - 6 } & 1. Yıl & 2. Yıl & Ort. & 1. Yıl & 2. Yıl & Ort. \\
\hline Ankara-76 & $26.90 \mathrm{de}$ & $31.45 \mathrm{abc}$ & $29.17 \mathrm{c}$ & 92.35 & $89.90 \mathrm{bcde}$ & 91.12 \\
Ankara-84 & $27.50 \mathrm{de}$ & $30.32 \mathrm{bcd}$ & $28.91 \mathrm{c}$ & 103.05 & $95.95 \mathrm{abcde}$ & 99.50 \\
Apak2-3 & $30.65 \mathrm{cde}$ & $26.27 \mathrm{de}$ & $28.46 \mathrm{c}$ & 123.15 & $91.45 \mathrm{bcde}$ & 107.30 \\
Bozkır1-5 & $29.20 \mathrm{cde}$ & $30.20 \mathrm{bcd}$ & $29.70 \mathrm{c}$ & 84.50 & $95.70 \mathrm{abcde}$ & 90.10 \\
Faikbey & $30.40 \mathrm{cde}$ & $33.40 \mathrm{ab}$ & $31.90 \mathrm{abc}$ & 99.60 & $112.80 \mathrm{ab}$ & 106.20 \\
Checota & $27.60 \mathrm{de}$ & $35.52 \mathrm{a}$ & $31.56 \mathrm{bc}$ & 108.30 & $115.20 \mathrm{a}$ & 111.75 \\
Seydişehir & $27.50 \mathrm{de}$ & $30.15 \mathrm{bcd}$ & $28.82 \mathrm{c}$ & 99.00 & $80.00 \mathrm{e}$ & 89.50 \\
Yeşilköy-330 & $25.17 \mathrm{e}$ & $24.12 \mathrm{e}$ & $24.65 \mathrm{~d}$ & 87.10 & $86.72 \mathrm{de}$ & 86.91 \\
Yeşilköy-1779 & $30.55 \mathrm{cde}$ & $27.45 \mathrm{cde}$ & $29.00 \mathrm{c}$ & 96.20 & $100.70 \mathrm{abcde}$ & 98.45 \\
Erzurum & $38.25 \mathrm{ab}$ & $32.92 \mathrm{ab}$ & $35.58 \mathrm{a}$ & 119.80 & $87.80 \mathrm{cde}$ & 103.80 \\
Amasya & $35.80 \mathrm{abc}$ & $28.52 \mathrm{bcde}$ & $32.16 \mathrm{abc}$ & 115.10 & $94.20 \mathrm{abcde}$ & 104.65 \\
Antalya & $32.15 \mathrm{bcd}$ & $32.00 \mathrm{abc}$ & $32.07 \mathrm{abc}$ & 100.88 & $91.25 \mathrm{bcde}$ & 96.06 \\
Tokat & $30.25 \mathrm{cde}$ & $32.27 \mathrm{abc}$ & $31.26 \mathrm{bc}$ & 102.70 & $86.85 \mathrm{de}$ & 94.77 \\
Ordu & $38.90 \mathrm{a}$ & $30.40 \mathrm{bcd}$ & $34.65 \mathrm{ab}$ & 123.80 & $104.07 \mathrm{abcd}$ & 113.93 \\
Sivas & $32.70 \mathrm{bcd}$ & $29.65 \mathrm{bcd}$ & $31.17 \mathrm{bc}$ & 97.60 & $104.60 \mathrm{abcd}$ & 101.10 \\
Çanakkale-Ovacık Köy & $31.10 \mathrm{cde}$ & $29.65 \mathrm{bcd}$ & $30.37 \mathrm{c}$ & 108.35 & $111.30 \mathrm{abc}$ & 109.82 \\
Samsun Ladik-ibiköyü & $31.25 \mathrm{cde}$ & $30.47 \mathrm{bcd}$ & $30.86 \mathrm{bc}$ & 90.85 & $101.10 \mathrm{abcde}$ & 95.97 \\
\hline Ortalama & $30.93^{* *}$ & $30.28 * *$ & $30.60 * *$ & 103.07 & $97.03 *$ & 100.05 \\
\hline \multirow{2}{*}{ P<0.01 } & & & & &
\end{tabular}

** $\mathrm{P}<0.01$ düzeyinde önemli, $* \mathrm{P}<0.05$ düzeyinde önemli

Gül ve ark. (1999)'da yaptıkları çalışmada, salkım uzunluğu yönünden genotipler arasındaki farkların önemli olduğunu belirtmişlerdir. Salkım uzunluğu yönünden yıllar arasındaki fark önemsiz bulunmuştur (Çizelge 5). Salkım uzunluğu yönünden yıl $x$ genotip interaksiyonu arasındaki fark önemli $(P \leq 0.01)$ olmuştur. Salkım uzunluğunun çevre koşullarından oldukça etkilendiği düşünülmektedir. Çünkü Ankara-76, Ankara-84, Bozkır 1-5, Faikbey, Checota, Seydişehir ve Tokat genotipleri salkım uzunluğu değerleri ikinci yıldan daha düşük bulunmuş ve interaksiyona sebep olmuşlardır.

\section{Salkımdaki tane sayısı}

Salkımdaki tane sayısı yönünden genotipler arasındaki farklar sadece ikinci yılda önemli bulunmuştur ( $P \leq$ 0.05). Birinci yıl ve iki yıllık birleştirilmiş analiz sonucuna göre çeşitler arasındaki farklar, yıllar arasındaki farklar ve yıl $x$ genotip interaksiyonu önemsiz olmuştur. Birinci yılda tane sayısı değerleri 84.50 adet ile 123.80 adet arasında değişmiştir. Salkımdaki tane sayısı ortalamaları birinci yılda 103.07 adet, ikinci yılda 97.03 adet olmuştur (Çizelge 5). Denemenin ikinci yılında, en yüksek salkımdaki tane sayısı Checota çeşidinden (115.20 adet) en düşük salkımdaki tane sayısı ise Seydişehir çeşidinden (80.00 adet) elde edilmiştir (Çizelge 5). Topal (1997), Gül ve ark. (1999)'da yaptıkları çalışmada genotipler arasındaki farkların salkımdaki tane sayısı bakımından önemli bulunduğunu belirtmişlerdir. Salkımdaki tane sayısı bakımından iki yılın birlikte analiz edilmesinde genotipler arasındaki farklar önemsiz olmuş, tane sayısı değerleri 113.93 adet ile 86.91 adet arasında tespit edilmiştir. 


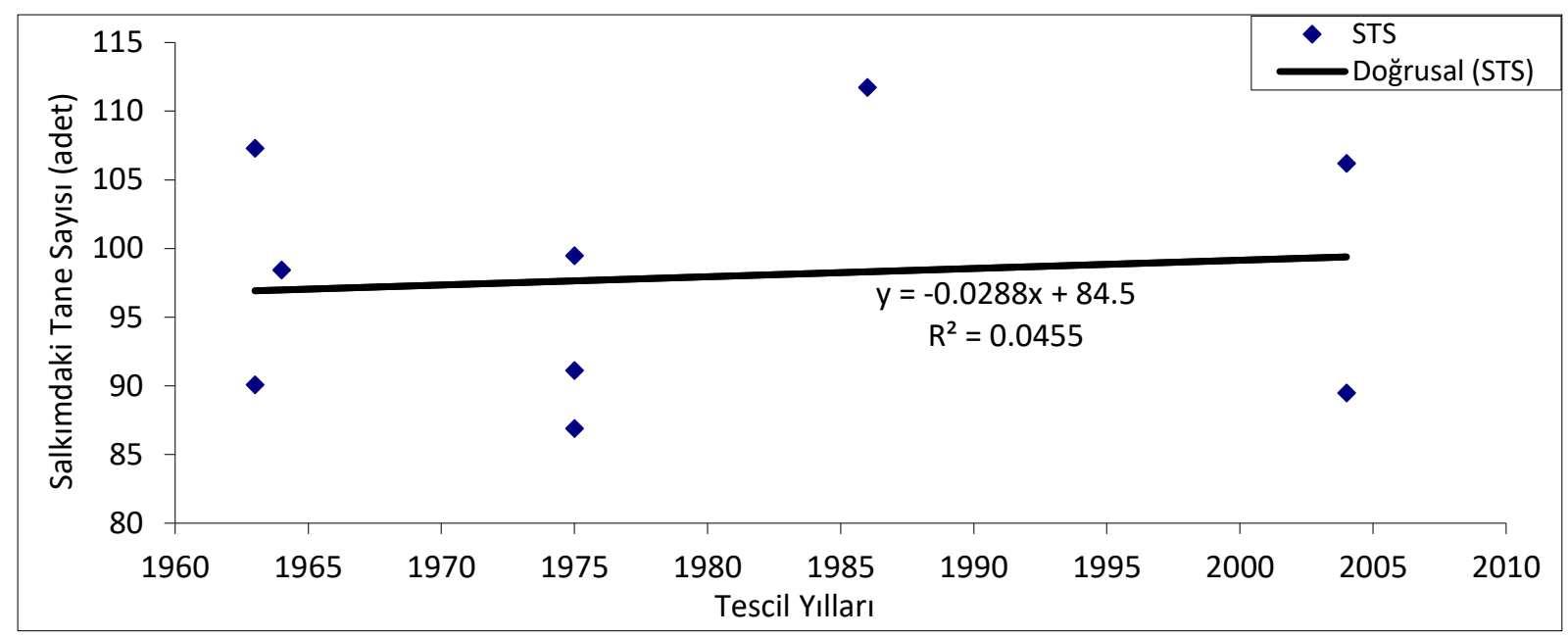

Şekil 2. Salkımdaki tane sayısı ile tescil yılları arasındaki ilişki (1960-2005).

Konu ile ilgili olarak daha önce yulafta yapılan çalışmalarda, benzer sonuçlar elde edilmiştir (Geçit ve Şahin, 1999; Gül ve ark. 1999; Inan ve ark., 2005; Kara ve ark., 2007). Rocquigny ve ark. (2004)'te yaptıkları bir çalışmada da tane sayısının çeşitlerden etkilenmediğini belirtmişlerdir. Kara ve ark. (2007)'de yulafta yaptıkları çalışmada, salkımdaki tane sayısını 58.8 - 92.5 adet arasında değiştiğini belirtmişlerdir. Yapılan başka bir çalışmada ise, salkımdaki tane sayısı bakımından genotipler arasındaki varyasyon her iki yılda da önemsiz bulunmuştur. İki yıllık veriler üzerinden yapılan varyans analizde de genotip ve yıl $x$ genotip interaksiyonu önemsiz bulunurken, yıllar arasındaki farkın önemli olduğu tespit edilmiştir, salkımdaki tane sayısı bakımından seleksiyon yapıldığında salkımdaki tane ağırlığının düştüğü bilinmektedir. Bunun için bu iki özelliğin tek başına seleksiyon kriteri olmasının doğru olamayacağını bildirmişlerdir (Dumlupınar ve ark., 2017).

Çizelge 6. Yulaf genotiplerinin salkımdaki tane ağırlığı ve tane dolum oranına ilişkin ortalama değerler

\begin{tabular}{|c|c|c|c|c|c|c|}
\hline \multirow{2}{*}{ Genotipler } & \multicolumn{3}{|c|}{ Salkımdaki tane ağırlığı (g) } & \multicolumn{3}{|c|}{ Tane dolum oranı (mg/tane/gün) } \\
\hline & 1. $Y_{I I}$ & 2. YII & Ort. & 1. YII & 2. $Y_{I I}$ & Ort. \\
\hline Ankara-76 & 2.06 & $2.95 \mathrm{abcd}$ & 2.50 & $0.062 \mathrm{c}$ & 0.098 & $0.080 \mathrm{bc}$ \\
\hline Ankara-84 & 2.69 & $2.53 \mathrm{~cd}$ & 2.61 & $0.081 \mathrm{abc}$ & 0.090 & $0.085 \mathrm{bc}$ \\
\hline Apak2-3 & 2.94 & $2.22 \mathrm{~d}$ & 2.58 & $0.104 a b$ & 0.099 & $0.101 \mathrm{ab}$ \\
\hline Bozkır1-5 & 2.25 & $3.35 \mathrm{ab}$ & 2.80 & $0.082 \mathrm{abc}$ & 0.131 & $0.106 a b$ \\
\hline Faikbey & 2.61 & $2.99 \mathrm{abc}$ & 2.80 & $0.112 \mathrm{a}$ & 0.109 & $0.110 \mathrm{ab}$ \\
\hline Checota & 3.36 & $2.76 \mathrm{abcd}$ & 3.06 & $0.108 \mathrm{a}$ & 0.096 & $0.102 a b$ \\
\hline Seydişehir & 2.62 & $2.68 \mathrm{bcd}$ & 2.65 & $0.086 a b c$ & 0.116 & $0.101 a b$ \\
\hline Yeşilköy-330 & 1.99 & $2.56 \mathrm{~cd}$ & 2.27 & $0.058 \mathrm{c}$ & 0.077 & $0.067 \mathrm{c}$ \\
\hline Yeşilköy-1779 & 2.37 & $2.64 \mathrm{bcd}$ & 2.50 & $0.080 a b c$ & 0.091 & $0.085 \mathrm{bc}$ \\
\hline Erzurum & 2.84 & $2.80 \mathrm{abcd}$ & 2.82 & $0.112 \mathrm{a}$ & 0.119 & $0.116 \mathrm{a}$ \\
\hline Amasya & 2.36 & $2.88 \mathrm{abcd}$ & 2.62 & $0.085 a b c$ & 0.118 & $0.101 \mathrm{ab}$ \\
\hline Antalya & 2.43 & $2.99 a b c$ & 2.71 & $0.070 \mathrm{bc}$ & 0.100 & $0.085 \mathrm{bc}$ \\
\hline Tokat & 2.80 & $2.94 \mathrm{abcd}$ & 2.87 & $0.080 a b c$ & 0.104 & $0.092 \mathrm{abc}$ \\
\hline Ordu & 2.94 & $3.43 \mathrm{a}$ & 3.19 & $0.099 a b$ & 0.131 & $0.115 \mathrm{a}$ \\
\hline Sivas & 3.05 & $2.34 \mathrm{~cd}$ & 2.69 & $0.085 a b c$ & 0.078 & $0.081 \mathrm{bc}$ \\
\hline Çanakkale-Ovacık Köy & 2.68 & $2.86 \mathrm{abcd}$ & 2.77 & $0.085 a b c$ & 0.104 & $0.095 \mathrm{abc}$ \\
\hline Samsun Ladik-İbiköyü & 3.18 & $2.82 \mathrm{abcd}$ & 3.00 & $0.113 \mathrm{a}$ & 0.092 & $0.102 a b$ \\
\hline Ortalama & 2.66 & $2.81^{*}$ & 2.73 & $0.088 * *$ & 0.103 & $0.096 * *$ \\
\hline
\end{tabular}

** $\mathrm{P}<0.01$ düzeyinde önemli, $* \mathrm{P}<0.05$ düzeyinde önemli.

Salkımdaki tane sayısı standart çeşitlerde 86.91- 111.75, yerel genotiplerde ise $94.78-113.93$ adet arasında değişmiş ve yerel genotiplerin daha yüksek tane sayısına sahip olduğunu bildirmişlerdir. Tescil yılları ile salkımdaki tane sayısı arasındaki ilişkinin belirlenmesi amacıyla yapılan regresyon analizi sonucunda, $y=0.0601 x-21.053$ şeklinde linear bir ilişkinin olduğu saptanmıştır (Şekil 2). Linear iliskiye ait $\mathrm{R}^{2}$ değerinin \% 1.1 olması, ilişkinin 
salkımdaki tane sayısındaki varyasyonun \% 1.1'ni açıklayabildiğini göstermektedir.

\section{Salkımdaki tane ağırlığı}

Salkımdaki tane ağırlığı yönünden genotipler arasındaki farklar sadece denemenin ikinci yılında önemli bulunmuştur ( $P \leq 0.05)$. Birinci yılda ve yılların birlikte analiz edilmesinde ise genotipler arasındaki farklar önemsiz olmuştur.

Denemenin birinci yılında, salkımdaki tane ağırıkları $1.99 \mathrm{~g}$ ile $3.36 \mathrm{~g}$ arasında değişmiş ve ortalama salkımdaki tane ağırlığı $2.66 \mathrm{~g}$ olarak saptanmıştır. İkinci yılda, 3.43 g ile 2.22 g arasında elde edilmiştir (Çizelge 6). Konu ile ilgili olarak daha önce yulafta yapılan çalışmalarda da bu araştırmanın sonucuna benzer şekilde salkımdaki tane ağırlığı bakımından çeşitler arasında önemli farklılıklar olduğu bildirilmiştir (Gül ve ark., 1999; Shah ve ark., 2002). Kara ve ark. (2007), yulafta yaptıkları çalışmada, salkımdaki tane ağırlığını 1.71 - 2.74 g arasında değiştiğini belirtmişlerdir.

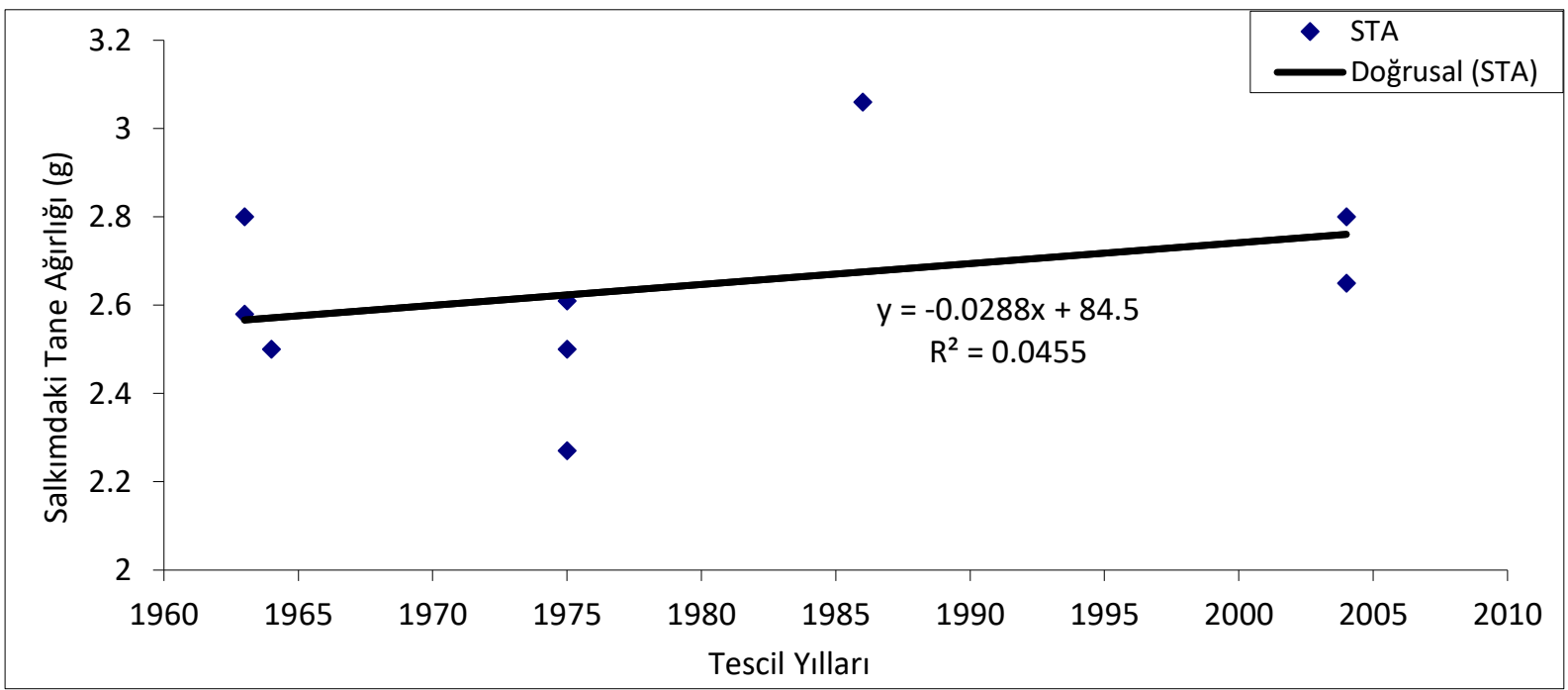

Şekil 3. Salkımdaki tane ağırığı ile tescil yılları arasındaki ilişki (1960-2005)

Denemede kullanılan standart çeşitlerden, Apak 2-3, Bozkır 1-5, Yeşilköy - 1779, Ankara -76, Ankara - 84, Yeşilköy - 330, Checota, Faikbey ve Seydişehir çeşitlerinin tescil yılları sırası ile 1963, 1963, 1964, 1975, 1975, 1975, 1986, 2004, 2004'tür. Tescil yılları ile salkımdaki tane ağırığı arasındaki ilişkinin belirlenmesi amacıyla yapılan regresyon analizi sonucunda, $y=0.0047 x-6.7157$ şeklinde linear bir ilişkinin olduğu saptanmıştır (Şekil 3). Linear iliskiye ait $R^{2}$ değerinin \% 11 olması, ilişkinin salkımdaki tane ağırlığındaki varyasyonun \% 11'ni açıklayabildiğini göstermekte olup, günümüze kadar tescil edilen çeşitlerin salkımdaki tane ağırlığı yönünden önemli bir ilerleme sağlanamadığı anlaşılmıştır.

\section{Tane dolum oranı}

Tane dolum oranı yönünden genotipler arasındaki farklar birinci yılda ve yılların birlikte analiz edilmesinde önemli ( $P \leq 0.01)$ olmuş, ikinci yıl ve yıl $x$ genotip interaksiyonu ise önemsiz olmuştur.

Denemede yıllar arasındaki farklar istatistiki bakımdan önemli ( $P \leq 0.01)$ olmuştur. Tane dolum oranı yönünden birinci yılda $0.11 \mathrm{mg} /$ tane/gün ile $0.058 \mathrm{mg} /$ tane/gün arasında değerler değişmiştir (Çizelge 6). Wych ve ark. (1982), yulafta yaptıkları bir çalışmada, tane dolum oranı bakımından yıllar arasında farklılıkların kısa olduğunu bildirmişlerdir. İki yıllık ortalama sonuçlarına bakıldığında ise değerlerin $0.11 \mathrm{mg} /$ tane/gün ile $0.067 \mathrm{mg} /$ tane/gün arasında değiştiği görülmüştür. Gebeyehou ve ark. (1982); Öztürk ve Akkaya (1994) gibi araştırıcılar tane dolum oranı yönünden çeşitler arasındaki farkların önemli olduğunu belirtmişlerdir. Triboi (1991), tane dolum oranının tane ağırlığını en fazla etkileyen özellik olduğunu ve tane dolum oranının metrekaredeki başak sayısı tarafından kontrol edildiğini belirtmiştir. Tane dolum oranı ve tane dolum periyodu arasında olumsuz ilişkinin görüldüğünü, tane dolum periyodu uzasa bile tane dolum oranının düşük olmasından kaynaklanan verim kaybının telafi edilemediğini belirtmiştir.

\section{Tane dolum indeksi}

Tane dolum indeksi yönünden genotipler arasındaki farklar birinci yılda, ikinci yılda ve yılların birlikte analiz edilmesinde istatistiki olarak önemli bulunmuştur ( $P \leq$ 0.01). Yıllar arasındaki fark istatistiki bakımdan önemli ( $P \leq 0.01)$ olmuştur. Tane dolum indeksi yönünden, birinci yılda 0.16 ile 0.11 değerleri arasında olmuştur (Çizelge 7). Denemenin ikinci yılında, en yüksek tane dolum indeksi değeri 0.15 ile Checota çeşidinden elde edilmiş, en düşük değer ise 0.12 ile Amasya genotipinden elde 
edilmiştir. iki yıllık ortalama sonuçlarına bakıldığında ise değerler 0.15 ile 0.12 arasında değişmiştir. Öztürk ve Akkaya (1994)'nin yaptığı çalışmada, genotipler arasındaki farkların önemli bulunduğunu belirtmişlerdir. Yıllar arasındaki farklara bakıldığında ise birinci yılda 0.14, ikinci yılda ise 0.13 değerleri elde edilmiştir (Çizelge 7).

Genotiplerin yıllara göre kararlı bir durum göstermemeleri yıl $\mathrm{x}$ genotip interaksiyonunun istatistiki olarak önemli çıkmasına neden olmuştur $(P \leq 0.01)$. Birinci ürün yılında, çiçeklenme sonrası yağış ve sıcaklık yönünden daha elverişli koşulların olması, daha uzun tane dolum periyodu, dolayısıyla daha fazla ekim-olgunlaşma süresi sağlamıştır. Böylece birinci yılda ikinci yıldan daha yüksek tane dolum indeksi değeri elde edilmiştir.

Çizelge 7. Yulaf genotiplerinin tane dolum indeksi ve tane protein oranına ilişkin ortalama değerler

\begin{tabular}{lcccccc}
\hline \multirow{2}{*}{ Genotipler } & \multicolumn{3}{c}{ Tane dolum indeksi } & \multicolumn{2}{c}{ Tane protein oranı (\%) } \\
\cline { 2 - 6 } & 1. Yıl & 2. Yıl & Ort. & 1. Yll & 2. Yıl & Ort. \\
\hline Ankara-76 & $0.15 \mathrm{ab}$ & $0.13 \mathrm{bcde}$ & $0.14 \mathrm{bcdef}$ & 12.97 & 13.19 & 13.08 \\
Ankara-84 & $0.15 \mathrm{ab}$ & $0.13 \mathrm{abcde}$ & $0.14 \mathrm{abcd}$ & 12.36 & 13.49 & 12.92 \\
Apak2-3 & $0.13 \mathrm{cde}$ & $0.13 \mathrm{bcde}$ & $0.13 \mathrm{fgh}$ & 12.44 & 13.92 & 13.18 \\
Bozkır1-5 & $0.12 \mathrm{de}$ & $0.12 \mathrm{de}$ & $0.12 \mathrm{gh}$ & 12.11 & 12.74 & 12.43 \\
Faikbey & $0.11 \mathrm{f}$ & $0.13 \mathrm{bcde}$ & $0.12 \mathrm{~h}$ & 12.53 & 13.95 & 13.24 \\
Checota & $0.14 \mathrm{bc}$ & $0.15 \mathrm{a}$ & $0.15 \mathrm{abcd}$ & 11.87 & 12.93 & 12.40 \\
Seydişehir & $0.14 \mathrm{bc}$ & $0.12 \mathrm{cde}$ & $0.13 \mathrm{efg}$ & 13.26 & 12.68 & 12.97 \\
Yeşilköy-330 & $0.15 \mathrm{ab}$ & $0.15 \mathrm{ab}$ & $0.15 \mathrm{ab}$ & 13.01 & 12.57 & 12.79 \\
Yeşilköy-1779 & $0.14 \mathrm{~cd}$ & $0.14 \mathrm{abcd}$ & $0.14 \mathrm{cdef}$ & 13.10 & 13.28 & 13.19 \\
Erzurum & $0.11 \mathrm{ef}$ & $0.13 \mathrm{bcde}$ & $0.12 \mathrm{gh}$ & 13.76 & 12.46 & 13.11 \\
Amasya & $0.13 \mathrm{cde}$ & $0.12 \mathrm{e}$ & $0.12 \mathrm{gh}$ & 11.46 & 13.79 & 12.63 \\
Antalya & $0.16 \mathrm{a}$ & $0.13 \mathrm{cde}$ & $0.14 \mathrm{abcde}$ & 12.68 & 13.19 & 12.94 \\
Tokat & $0.16 \mathrm{a}$ & $0.13 \mathrm{abcde}$ & $0.15 \mathrm{abc}$ & 12.72 & 12.61 & 12.66 \\
Ordu & $0.13 \mathrm{~cd}$ & $0.12 \mathrm{de}$ & $0.13 \mathrm{fgh}$ & 11.99 & 14.95 & 13.47 \\
Sivas & $0.16 \mathrm{a}$ & $0.14 \mathrm{abc}$ & $0.15 \mathrm{a}$ & 12.22 & 13.05 & 12.63 \\
Çanakkale-Ovacık Köy & $0.14 \mathrm{bc}$ & $0.13 \mathrm{bcde}$ & $0.14 \mathrm{cdef}$ & 12.61 & 12.64 & 12.62 \\
Samsun Ladik-ibiköyü & $0.13 \mathrm{cde}$ & $0.14 \mathrm{abc}$ & $0.13 \mathrm{def}$ & 13.17 & 12.85 & 13.01 \\
\hline Ortalama & $0.14 * *$ & $0.13 * *$ & $0.13 * *$ & 12.60 & 13.19 & 12.90 \\
\hline
\end{tabular}

** $\mathrm{P}<0.01$ düzeyinde önemli

\section{Tanede protein oranı}

Tanedeki protein oranı bakımından genotipler arasındaki farklar birinci yıl, ikinci yıl ve iki yıl birleştirilmiş analiz sonuçlarına göre önemsiz çıkmıştır. Yıllar arasındaki fark istatistiki olarak önemli $(P \leq 0.01)$ bulunmuştur.

Genotipler arasındaki farklar önemsiz olup, birinci yılda protein oranı değerleri \% 11.46 ile \% 13.76 arasında değişmiştir. İkinci yılda ise \% 12.46 ile \% 14.95 arasında değişmiştir (Çizelge 7). İki yılın ortalaması olarak ise protein oranı bakımından 17 genotipin ortalaması \% 12.90 olarak saptanmıştır. Protein oranının yüksek olmasının besleme değerini artırması açısından önemli olduğunu ve istenen bir özellik olduğunu belirtmişlerdir (Şahin ve ark., 2019). Genotiplerin tane protein oranı bakımından yıllara göre kararsızlık göstermeleri, yıl $x$ genotip interaksiyonunun önemli $(P \leq 001)$ çıkmasına neden olmuştur. Peterson ve ark. (2005), yulafta yaptıkları çalışmada, yıl $x$ genotip interaksiyonu yönünden protein miktarının bakımından önemli farklılıklar oluştuğunu, protein miktarı üzerinde çevre ve genotipin büyük etkisinin olduğunu belirtmişlerdir (Doehlert ve ark., 2001).
Protein miktarının önemli ölçüde genotipe bağlı olmasına karşın büyük ölçüde çevreden etkilendiğini bildirmişlerdir (Stone ve Savin, 2000; Johansson ve ark. 2003). Yapılan başka bir çalışmada ise yulaf çeşitlerinde protein oranının; \%7.6 ile \%22.2 arasında değişiklik gösterdiği belirlenmiştir (Sarı ve ark., 2012). Kahraman ve ark., (2017)'nın genotiplerin protein oranlarının \%9.0-15.2 arasında değiştiğini bildirirken, Naneli ve Sakin (2017), protein miktarının \%10.1 ile \%14.1 arasında değiştiğini bildirmişlerdir.

\section{incelenen özellikler arasındaki ilişkiler}

İki yıllık ortalama değerler üzerinden incelenen özellikler arasında hesaplanan korelasyon katsayıları Çizelge 8'de verilmiştir. Çizelgede görüldüğü gibi;

Ekim-olgunlaşma süresi ile tane dolum periyodu ( $\left.r=0.53^{*}\right)$ arasında, salkım uzunluğu ile; bitki boyu ( $\left.r=0.68^{* *}\right)$ arasında, salkımdaki tane sayısı ile; bitki boyu ( $\left.r=0.60^{*}\right)$ ve salkım uzunluğu ( $r=$ 0.59*) arasında, salkımdaki tane ağırlığı ile; bitki boyu $\left(r=0.77^{* *}\right)$, salkım uzunluğu $\left(r=0.74^{* *}\right)$ ve salkımdaki tane sayısı $\left(r=0.57^{*}\right)$ arasında olumlu ve 
önemli bir ilişkiler tespit edilmiştir. Bitki boyu ile; tane dolum periyodu $\left(r=-0.67^{* *}\right)$ arasında olumsuz ve önemli ilişkiler olduğu belirlenmiştir.

Tane dolum oranı ile; bitki boyu $\left(r=0.91^{* *}\right)$, salkım uzunluğu ( $\left.r=0.71^{* *}\right)$, salkımdaki tane sayısı $\left(r=0.55^{*}\right)$ ve salkımdaki tane ağırlığı $\left(r=0.73^{* *}\right)$ arasında olumlu ve önemli, tane dolum periyodu $(r=$ $-0.79 * *$ ) ile arasında olumsuz ve önemli ilişkiler olduğu saptanmıştır. Gebeyohu ve ark. (1982), tane dolum oranının, tane ağırlığı ile olumlu ve önemli ilişki içerisinde olduğunu, Sayed ve Gadallah (1983), tane dolum oranının tane sayısı ile ilişkili olduğunu bildirmişlerdir. Yang ve ark. (2008), tane dolum süresi ile tane dolum oranı arasında negatif bir korelasyon olduğunu, tane dolum oranının tane ağırlığı üzerine etkisinin negatif yönde veya önemsiz çıktığını belirtmişlerdir. Tane dolum indeksi ile; tane dolum periyodu $\left(r=0.99^{* *}\right)$ arasında olumlu ve önemli, bitki boyu ( $\left.r=-0.68^{* *}\right)$ ve tane dolum oranı $\left(r=-0.78^{* *}\right)$ arasında olumsuz ve önemli ilişkiler belirlenmiştir.

Çizelge 8. İncelenen özellikler arası ilişkilere ait korelasyon katsayıları

\begin{tabular}{cccccccccc}
\hline & $\mathbf{1}$ & $\mathbf{2}$ & $\mathbf{3}$ & $\mathbf{4}$ & $\mathbf{5}$ & $\mathbf{6}$ & $\mathbf{7}$ & $\mathbf{8}$ & $\mathbf{9}$ \\
\hline $\mathbf{1}$ & 1.00 & & & & & & & & \\
$\mathbf{2}$ & $0.53^{*}$ & 1.00 & & & & & & \\
$\mathbf{3}$ & 0.28 & 0.03 & 1.00 & & & & & \\
$\mathbf{4}$ & $-0.67^{* *}$ & -0.18 & -0.44 & 1.00 & & & & \\
$\mathbf{5}$ & -0.44 & -0.41 & -0.09 & $0.68^{* *}$ & 1.00 & & & \\
$\mathbf{6}$ & -0.27 & -0.14 & -0.32 & $0.60^{*}$ & $0.59^{*}$ & 1.00 & & \\
$\mathbf{7}$ & -0.23 & -0.07 & -0.17 & $0.77^{* *}$ & $0.74^{* *}$ & $0.57^{*}$ & 1.00 & & \\
$\mathbf{8}$ & $-0.79 * *$ & -0.40 & -0.22 & $0.91^{* *}$ & $0.71^{* *}$ & $0.55^{*}$ & $0.73^{* *}$ & 1.00 & \\
$\mathbf{9}$ & $0.99 * *$ & 0.47 & 0.30 & $-0.68^{* *}$ & -0.42 & -0.26 & -0.22 & $-0.78^{* *}$ & 1.00 \\
$\mathbf{1 0}$ & -0.36 & -0.18 & -0.34 & 0.27 & 0.19 & 0.17 & 0.02 & 0.23 & -0.36 \\
\hline
\end{tabular}

** $\mathrm{p} \leq 0.01, * \mathrm{p} \leq 0.05$ hata sınırları içinde istatistiksel olarak önemli. 1= tane dolum periyodu 2= ekim-olgunlaşma süresi $3=$ metrekaredeki salkım sayısı $4=$ bitki boyu $5=$ salkım uzunluğu $6=$ salkımdaki tane sayısı $7=$ salkımdaki tane ağırlığı $8=\operatorname{tane}$ dolum oranı $9=$ tane dolum indeksi $10=$ tanede protein oranını göstermektedir.

\section{Sonuç ve Öneriler}

Araştırmada materyal olarak kullanılan 8 yerel ve 9 tescilli yulaf çeşitleri incelenen, tane dolum periyodu, ekim-olgunlaşma süresi, bitki boyu, salkım uzunluğu, tane dolum oranı ve tane dolum indeksi özellikleri bakımından önemli ölçüde farklı bulunmuştur. İncelenen bazı özellikler bakımından ise genel olarak genotipler ve çeşitler arasında birbirine yakın değerler elde edilmiştir. Bu çalışmada, Sivas ve Yeşilköy-330 genotipleri tane dolum periyodu ve tane dolum indeksi yönünden; en erkenci çeşit olan Faikbey çeşidi ile birlikte Ankara-84 çeşidi ve Erzurum genotipi ekim olgunlaşma süresi yönünden; Seydişehir çeşidi metrekaredeki salkım sayısı yönünden; Yeşilköy-330 çeşidi bitki boyu yönünden; Erzurum genotipi salkım uzunluğu ve tane dolum oranı yönünden; Ordu genotipi salkımdaki tane sayısı, salkımdaki tane ağırlığı ve tane protein oranı bakımından ön plana çıkmışlardır. Bu sonuçlar bazı yerel çeşitlerin ümitvar olduklarını göstermektedir.

\section{Kaynaklar}

Batalova, G.A., Shevchenko, S.N., Tulyakova, M.V., Rusakova, I.I., Zheleznikova, V.A.,Lisitsyn, E.M. 2016. Breeding of naked oats having high-quality grain. Russian Agricultural Sciences, 42(6): 407-410.
Browne, R. A., White, E. M., Burke, J. I. 2006. Responses of developmental yield formation processes in oats variety, nitrogen, seed rate and plant growth regulator, and their relationship to quality. J. Of Agron. Sci., 144(6): 533-545.

Buerstmayr, H., Krenn, N., Stephan, U., Grausgruber, H., Zechner, E. 2007. Agronomic performance and quality of oat (Avena sativa L.) genotypes of worldwide origin produced under Central European growing conditions. Field Crop Research, 101: 343-351.

Coşkun, T. 2005. Fonksiyonel besinlerin sağlığımız üzerine etkileri. Çocuk Sağlığı ve Hastalıkları Dergisi, 48(1): 69-84.

Doehlert, C. D., Mcmullen, M. S., Hammond, J. J. 2001. Genotypic and environmental effects on grain yield and quality of oat grown in North Dakota. Crop Science, 41: 1066-1072.

Dokuyucu, T., Peterson, D. M.., Akkaya, A. 2003. Contents of antioxidant compounds in Turkish Oats: Simple phenolics and avenanthramide concentrations. Cereal Chemistry, 80(5): 542-543.

Dumlupınar Z., Tekin A., Herek S., Tanrıkulu A., Dokuyucu T. ve Akkaya A. 2017. Türkiye Kökenli Yulaf Genotiplerinin Bazı Tarımsal 
Özellikler Bakımından Değerlendirilmesi. Türk Tarım - Gıda Bilim ve Teknoloji Dergisi, 5(7): 763-772.

Dumlupınar, Z. 2010. Türkiye orijinli yerel yulaf genotiplerinin avenin proteinleri ile morfolojik, fenolojik ve agronomik ozellikler yonunden karakterizasyonu. KSÜ Fen Bil. Enst. Tarla Bitkileri ABD, Doktora Tezi, 126 sy, Kahramanmaraş.

Ercan, K., Tekin, A., Herek, S., Kurt, A., Kekeç, E., Olgun, M.F., Dokuyucu, T., Dumlupınar, Z. ve Akkaya, A., 2016. Yerel Yulaf Hatlarının Kahramanmaraş Koşullarındaki Performansı. K.S.Ü Doğa Bilimleri Dergisi, 19(4), 438-444.

Gebeyehou, G., Knott, D. R., Baker, R. J. 1982. Rate and Duration of filling in durum wheat cultivars. Crop Science, 22: 337-340.

Geçit, H. H., Şahin, N. 1999. Yulafta ekim sıklıklarına göre anasap ve çeşitli kademedeki kardeşlerde bazı verim öğelerinin değişimi. Türkiye 3. Tarla Bitkileri Kongresi, 15-18 Kasım, Adana, Cilt I, s.192-197.

Gupta, N. K., Gupta, S., Kumar, A. 2001. Effect of Water stress on physiological attributes and their relationship with growth and yield of wheat cultivars at different stages. Crop Science, 41: 1390-1395.

Gül, İ., Akıncı, C., Çölkesen, M. 1999. Diyarbakır Koşullarına uygun tane ve ot amaçlı yetiştirilebilecek yulaf çeşitlerinin belirlenmesi. Hububat Sempozyumu, 8-11 Haziran, Konya, s.117-125.

Helland, S. J., Holland, J. B. 2001. Blend Response and stability and cultivar blending ability in oat. Crop Science, 41(6): 1689-1696.

İnan, A. S., Özbaş, M. O., Çağırgan, M. İ. 2005. İnsan Beslenmesinde kullanılan yulaf hatlarının tarımsal ve kalite özellikleri bakımından değerlendirilmesi. Türkiye VI. Tarla Bitkileri Kongresi. 5-6 Eylül 2005, Antalya (Araştırma Sunusu) Cilt II, s. 1153-1155.

Jaradat, A. A., Ajluni, M. M., Karaki, G. 1996. Genetic Structure of durum wheat landraces in a center of diversity. 5th International Wheat Conference Abstracts, pp. 10-14.

Johansson, E., Prieto-Linde, M. L., Svensson, G., Jönsson, J. Ö. 2003. Influences of cultivar, cultivation year and fertilizer rate on amount of protein groups and amount and size distribution of mono- and polymeric proteins. J. Agric. Sci., 140: 275-284.

Kahraman, T., Avcl, R., Kurt, C., 2017. Bazı yulaf (Avena sativa L.) genotiplerinin tane verimi, kalite ve tarımsal özelliklerinin belirlenmesi. Tarla Bitkileri Merkez Araştırma Enstitüsü Dergisi, 2017, 26 (Özel Sayı): 74-79.
Kara, R., Dumlupınar, Z., Hışır, Y., Dokuyucu, T., Akkaya, A. 2007. Kahramanmaraş koşullarında yulaf çeşitlerinin tane verimi ve verim unsurları bakımından değerlendirilmesi. Türkiye VII. Tarla Bitkileri Kongresi, 25-27 Haziran 2007, s. 121-125.

Karabulut, A., 1995. Yemler Bilgisi ve Yem Teknolojisi. U.Ü. Zir. Fak. Ders Notları, No: 67, s. 164-170, Bursa.

Kün, E. 1983. Serin İklim Tahılları. A. Üniv. Ziraat Fak. Yayınları, No: 875, Ders Kitabı No: 240, 307 s.

Kün, E. 1988. Serin İklim Tahılları. A.Ü. Ziraat Fak. Yayınları No: 1032, Ders Kitabı No: 299, 216 s.

Naneli, I., Sakin, M.A., 2017. Bazı Yulaf Çeşitlerinin (Avena sativa L.) Farklı Lokasyonlarda Verim ve Kalite Parametrelerinin Belirlenmesi. Tarla Bitkileri Merkez Araştırma Enstitüsü Dergisi, 26 (Özel sayı): 37-44.

Özberk İ. 2018. Mezopotamya'nın yerel buğdayları. Türkiye Yerel Buğdaylar Sempozyumu, Sayfa 40-42, 20-22 Aralık 2018, Bolu; Türkiye. In Turkish-Abstract].

Öztürk, A., Akkaya, A. 1994. Kışılk buğday genotiplerinde vejetatif periyod, tane dolum periyodu ve tane dolum oranı ile verim ve verim unsurları arasındaki ilişkiler. Tarla Bitkileri Kongresi, 25-29 Nisan 1994, Cilt I, Agronomi Bildirileri, Bornova, İzmir.

Peterson, D. M., Wesenberg, D. M., Burrup, D. E., Erickson, C. A. 2005. Relationships among agronomic traits and grain composition in oat genotypes grown in different environments. Crop Science, 45(4): 1249.

Rocquigny, P. J., Entz, M. H., Gentile, R. M., Duguid, S. D. 2004. Yield Physiology of a semi dwarf and tall oat cultivar. Crop Science, 44(6): 2116.

Sarı N., İmamoğlu A. ve Yıldız Ö., 2012. Menemen Ekolojik Koşullarında Bazı Ümitvar Yulaf Hatlarının Verim ve Kalite Özellikleri. Journal of $A A R I, 22$ (1), 18-32 .

SAS Institute, 1999. SAS Institute Inc., SAS/STAT ${ }^{\circ}$ User's Guide, Version 8, SAS Institute Inc., Cary, NC (1999).

Sayed, H. I., Gadallah, A. M. 1983. Variation in dry matter and grain filling characteristics in wheat cultivars. Field Crops Research, 7: 6171.

Shah, W. A., Bakht, J., Shafi, M., Khan, M. A. 2002. Yield and Yield components of different cultivars of wheat barley and oat under rainfed conditions. Asian J. of Plant Sci., 1(2): 148-150. 
Sönmez, A.C., Karaduman Y., 2020. Grain Yield and Some Quality Traits of Local Oat (Avena sativa L.) Genotypes under Eskişehir Conditions. Turkish Journal of Agriculture Food Science and Technology, 8(8): 16971704.

Stone, P. J., Savin, R. 2000. Grain Quality and Its Physiological Determinants. In: Satorre, M. H., Slafer, G. A. (Eds), Wheat, Ecology and Physiology of Yield Determination. Food Products Pres., New York, pp. 85-120.

Şahin M, Çeri S, Akçacık AG, Aydoğan S, Hamzaoğlu S, Demir B. 2019. Kışlık Yulaf (Avena sativa spp.) Genotiplerinin Verim ve Teknolojik Özellikleri Arasındaki iliş̧kilerin İncelenmesi. Bahri Dağdaş Bitkisel Araştırma Dergisi, 8(1): 34-42.

Topal, A. 1997. Yulaf çeşitlerinde verimi etkileyen bazı morfolojik karakterler üzerine bir araştırma. Selçuk Üniv. Ziraat Fak. Derg. 11(15): 30-38.

Triboi, E. 1991. The Formation of Grain Weight in Wheat. Field Crop Abst., 44(1): 59.

Wood, M. 2001. New oats and barleys, ready for breakfast, brewery, or bran. Agricultural Research, 49(8): 18-19.
Wych, R. D., Mcgraw, R. L., Stuthman, D. D. 1982. Genotype $X$ year interaction for length and rate of grain filling in Oats. Crop Science, (22): 1025-1028.

Yang, W., Peng, S., Dionisio-Sese, M., Laza, R. C., Visperas, R. M. 2008. Grain filling duration, a crucial determinant of genotypic variation of grain yield in field - grown tropical irrigated rice. Field Crops Research, 105: 221-227.

Yılmaz, N. 1996. Van ekolojik koşullarında bazı yulaf çeşit ve hatlarının verim ve verim öğeleri üzerinde bir araştırma. Türkiye 3. Çayır Mer'a ve Yem Bitkileri Kongresi, 17-19 Haziran 1996, Erzurum.

Yürür, N. 1994. Serin İklim Tahılları (Tahıllar-I). Uludağ Üniversitesi Ziraat Fakültesi Yayınları: 030-0256, Ders Kitabı, s. 220. U. Üniv. Basımevi, Bursa.

Zadoks, J. C., Chang, T. T., Konzak, C. F. 1974. A Decimal Code for the Growth Stages of Cereals. Weed Res. 14: 415-421. 